\title{
Changes in culture and matchmaking behavior: online dating on Tinder
}

\author{
Fransisca Benedicta Avira Citra Paramita \\ Master Program in Media and Communication \\ Faculty of Social and Political Sciences, Universitas Airlangga, Surabaya \\ Address: Jalan Airlangga No. 4-6, Surabaya, Indonesia \\ E-mail: fransisca.benedicta.fb@gmail.com
}

\begin{abstract}
Whether humans drive technology or technology capable of moving human life systems is still a debate and a contradiction in the thinking of some humans. Technological progress in Indonesia itself cannot be denied. What is feared is that the diversity of cultures and languages in Indonesia is threatened with extinction. One of the cultures that used to be felt in Indonesia was the culture of finding a mate. In ancient times, searching for a mate used traditional methods or more thick and trusting through elements of the surrounding culture and customs. However, with the development of technology began to erode the custom of finding a mate, which was replaced by technology's role. In this study, researchers focused on how technology replaces the role of culture, customs, and religion in finding someone's mate using social media applications. The theory used is to use determinism technology theory, which tries to prove that technology is starting to replace humans' role. This study took interviews with eight female informants from different ethnicities, religions, and ages. This study indicates that human trust in technology is now greater than the culture or customs that are still held firmly by the Indonesian people.
\end{abstract}

Keywords: technology; determinism; online dating

Article History

Received: April 13, $2021 \quad$ Accepted: June 10, 2021

Cite this as: Paramita FBAC (2021) Changes in culture and matchmaking behavior: online dating on Tinder. Indonesian Journal of Social Sciences 13 (1):33-45. DOI 10.20473/ijss.v13i1.26353.

\section{Introduction}

This study sees that the role of technology is now very large and has entered human life. Today's technology is no longer used as a tool to help human activities, but humans have become a tool used for the development of technology even now. In Indonesia, this can already be felt because devices such as androids, smartphones, laptops, and other sophisticated devices have been created to erode Indonesia's existing culture. This research's focus lies in one of the application features located on social media, which in its current application has eroded culture and customs in Indonesia.

The application is a matchmaking application called "Tinder". As reported by Jek (2018) in www.liputan6.com, this tinder application is one of the best matchmaking applications that Indonesians often use to find a mate. In this application, many people believe that this application's emergence helps someone find a lover through the "Jodohkan Lalu Kencan Online" (or Match then Online Dating) feature on Tinder. In this feature, a person selects a partner by swiping or shifting the photo and determining whom he thinks is the criteria for the partner they want. In this feature, someone can determine the partner they choose according to the criteria for their desired age, position, and location. Figure 1 about the Tinder feature shows that the Tinder feature has provided a column for users who receive someone by pressing the "heart" button on the bottom right. In contrast, if users are not interested in that person, users can press the "cross" button in the column, bottom left. 
Some of the ways described above show that how technology is starting to replace human labor, especially culture in Indonesia. As stated by Irena (2017) in www.idntimes.com, the Indonesian State, which has a variety of ethnicities, cultures, and languages, is also unique when meeting or matching a partner for their descendants. In certain areas, the customs are still very strong, that the pair of the chosen offspring must follow the position or be born from the same descent. For example, the Batak' descendants must marry the descendants of the Batak as well and many more.

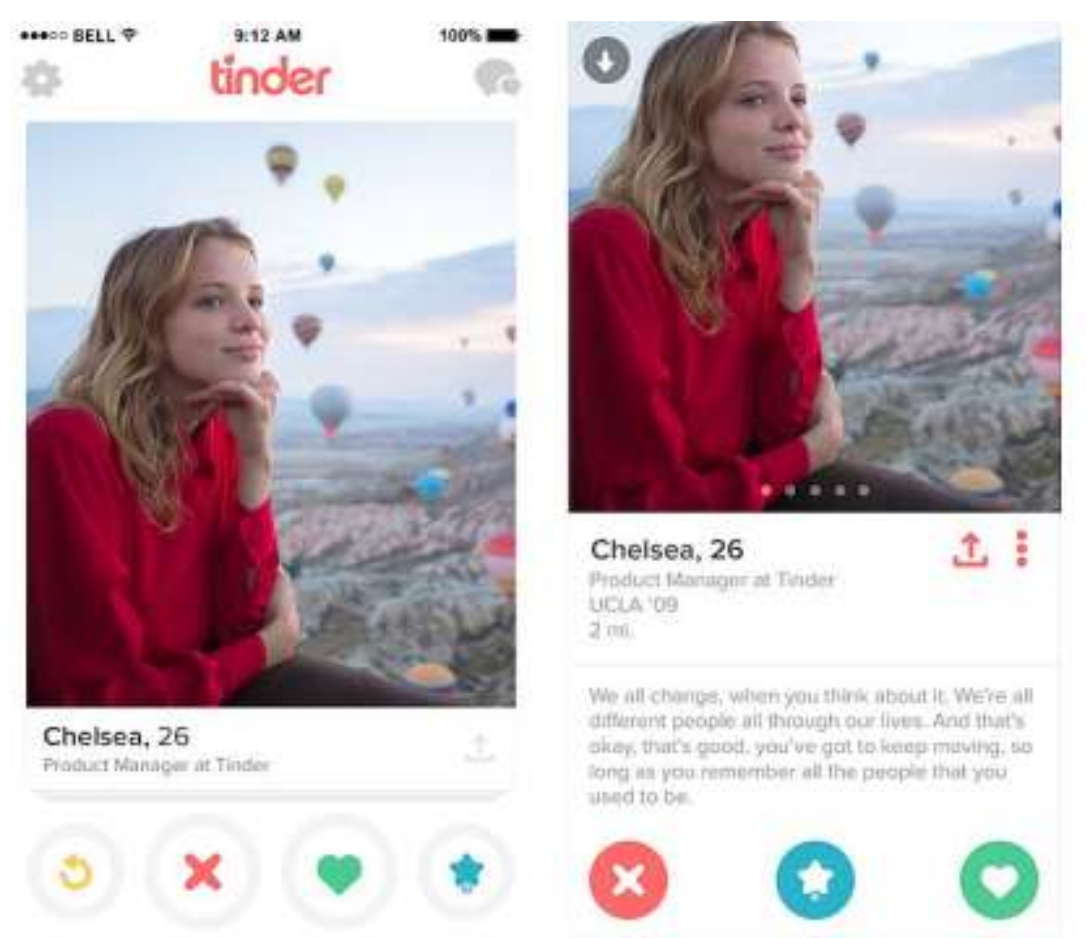

Figure 1.

The Tinder feature application

(gadgets.ndtv.com)

This assumption is also explained by Manik (2012), who provides an example of the Toba Batak Community's customs, namely Sinamot. In the Toba Batak community, the family will be more selective when looking for a mate for children. Even some families prefer to find and choose a mate for their children to carry out this mandatory tradition, namely Sinamot.

This research becomes interesting because of how technology replaces humans' role. These features no longer use customs or cultures by meeting through family, matchmaking culture, and others. The features presented in the application seem to make it easier for humans to find the partner they want. In this study, the theory of determinism technology is used more because, according to Nurhadi \& Irwansyah (2018), everything that becomes people's behavior today can be changed and determined by technological developments. Humans are considered to have a dependency or tendency towards technology.

In previous research on the Tinder application, this application emphasized why humans choose to find a partner or mate. However, this research emphasizes how technology through the Tinder application changes the existing culture in Indonesia. Researchers can identify this by interviewing eight female resource persons from different family and ethnic backgrounds. Researchers took female sources because, in Indonesian culture, it is not to be aggressive when looking for a woman's soul mate. Every celebration, it is men who come to women and men looking for their soul mate. 
However, this increasingly sophisticated technological development has changed the order that women are also looking for and actively seeking their soul mate.

\section{Methods}

This study used a qualitative method, in which the researcher conducted interviews with eight sources who had used the Tinder application to find a mate. Table 1 shows that the eight resource persons with quite diverse religions have experience using matchmaking applications in different ways and backgrounds. In this study, the analysis results were carried out by interviewing eight female resource persons of various ethnicities and ages. Researchers took female sources aged 18-45 years because it is enough age for Indonesians to find a life partner. The eight resource persons also have diverse family backgrounds with culture, education, and experiences to find different partners. Researchers selected eight sources who have experience finding a partner through a matchmaking application, which in this study is the Tinder application. The following is a description of the eight sources that the researchers interviewed as follows.

Table 1.

List of informants

\begin{tabular}{ccccc}
\hline No. & Name $($ Initial) & Age & Ethnic & Religion \\
\hline 1 & $\mathrm{Fr}$ & 24 years & Minahasa & Christian \\
2 & $\mathrm{Me}$ & 31 years & Javanese & Christian \\
3 & $\mathrm{Pr}$ & 19 years & Chinese & Buddha \\
4 & $\mathrm{La}$ & 28 years & NTT & Catholic \\
5 & $\mathrm{Ka}$ & 17 years & Javanese & Christian \\
6 & $\mathrm{Ra}$ & 41 years & Javanese & Islam \\
7 & $\mathrm{Ss}$ & 25 years & Chinese & Christian \\
8 & $\mathrm{Ti}$ & 24 years & Javanese & Islam \\
\hline
\end{tabular}

The researcher identifies the extent to which the informants still use cultural development and cultural values as in the following identification.

\section{Results and Discussion}

\section{Determinism technology}

This section describes determinism technology theory and its application in Indonesia. Before entering into the definition of determinism technology, the author will define what is meant by technology. As Setianto \& Anandhita (2018) wrote, technology is a tool made to support human activities. Technology itself is the result of creativity from the human brain that should be used as a facility for humans, not the masters of humans.

That is also supported by Maryono \& Istiana's (2007) arguments, which explain that technology has the meaning of the development and application of various equipment or systems that are made to solve problems faced by humans. In word order, technology is defined as "procedures" because technology is the result of the human mindset to develop certain procedures or systems that aim to solve problems in human life. 
Through the two arguments above, it shows the true function and meaning of technology. However, the current cultural development says something different, namely starting to create a new culture where technology replaces humans' intelligence. There is an assumption that human intelligence has begun to be replaced by intelligence owned by technology.

Based on Mirza \& Dewi's (2019) assumption, who writes that technology supports an industrial revolution 4.0 with Artificial Intelligence's emergence, human intelligence switches to machines. That results in that the human brain has reduced its use because it is replaced by technology capable of replacing human intelligence.

After the emergence of the 4.0 industrial revolution, which gave rise to an understanding of IoT (Internet of Things), all technology is via the internet, making various human activities highly dependent on the internet and others (Mirza \& Dewi 2007). Some of the above assumptions are also embraced by the determinism theory of technology which assumes that technology has replaced human capabilities. This assumption is also explained by Lim (2008), who sees a more general opinion emerging initially through the view of social determinism, which believes that technology in itself cannot affect unless the technology is in human hands. In other words, the technology is neutral, but if the technology is in human hands, the technology will turn out to be non-neutral.

After explaining that the technology is neutral or not neutral, it leads to thoughts of technological determinism. In Ihde's thought written by Lim (2008) that after the technology is not neutral or technology is created, the view of determinism technology then emerges where technology becomes autonomous and dominates human life. Technology is both a means and an end between humans and the world.

That was also agreed by Ellul, who was written in Lim (2008), that technology is an uncontrolled autonomous force because technology enslaves humans instead of liberating them. Ellul said that today's society is technological. Technology is often seen as liberating humans from superstition; however, technology is often seen as liberating in a technological society, but technology shackles it. McLuhan (1994) also stated that technology shapes individuals. Technology influences the way of thinking behave in society and directs humans to move from one technological century to another. The concept brought up by McLuhan then brought some agreeable perspectives on the presence of technology.

In the theory of determinism, technology also states that technology determines or changes society's attitudes and behavior. This case explains that everything that becomes people's behavior today can be changed and determined by technological developments. Humans are considered to have a dependency or tendency towards technology. The theory of technological determinism also explains that "Technology is the opiate of society" (Nurhadi \& Irwansyah 2018). Through this, McLuhan (1964), in his perspective on determinism technology, also explains the pattern of human life, especially social interaction, which is very much determined by the development and type of technology controlled by humans. McLuhan's thinking changes occur in various ways of communicating, which will shape the pattern of human existence itself.

From several books written by McLuhan (2003) entitled "We Shape our tools and they, in turn, shape us" outline three frameworks from McLuhan about the theory of technological determinism, namely: First, the discovery of new things in communication technology will lead to cultural changes. Second, changes in human communication form human life. Third, humans form the necessary tools, but now things will turn around, namely the turn of the tools that shape humans.

\section{Technology and change}

This section describes the theory about technology that has changed several cultures in Indonesia. In this case, Indonesia itself has a variety of cultures that have different orders or rules. In terms of 
finding a mate or determining someone's mate, it also has different ways according to the diversity of tribes and customs in the area. That will then be described in the discussion below.

\section{Technology changes culture}

Every technological development will always present a change where there is convenience, efficiency, and increases in humans' productivity in these changes. According to Martono (2011) in Astuti \& Rps (2014), he mentions several things promised by technology, including 1.) Technology promises change. In this option, Martono (2011) explains that every discovery will give birth to various societal changes. Technology is considered to change the daily activities of individuals. 2.) Technology promises progress. Technology is a form of progress because every human being who accesses technology is considered to be experiencing progress in any form, including influencing the lifestyle's progress. 3.) Technology promises convenience. In this case, each technology was created to provide convenience for each individual. 4.) Technology promises productivity. Some advanced companies often take advantage of technology to increase productivity because technology is considered more efficient. 5.) Technology promises speed. In this case, the existence of technology aims to accelerate the performance of humans. 6.) Technology promises popularity. That can be seen through the ease with which humans appear on the screen via the internet. The internet is a technology that is often used to achieve a person's popularity.

The description of the promise of technology above shows that humans' changes are very dependent on the changes made by the technology. In this case, it will then be more focused on cultural changes adopted by the Indonesian people. As Koentjaraningrat (2002) wrote, Indonesian society is a diverse society in various ways such as culture, nature, and geographical areas. One of the aspects mentioned above is the cultural aspect. Culture can mean the values held by society or the perceptions held by Indonesians. Besides, culture also has the definition as a form of ideas, and it can also be attitude and the result of attitude.

The difference in cultural changes felt by the Indonesian people attacks the younger generation today. Because of the impact of technological developments attacking young people's lives, many new things are easier to teach by young people than parents. Astuti \& Rps (2014) also said that the generation of parents in general still really hold original values from Indonesia, such as religion or customs. However, the younger generation has left culture and prefers to like westernized culture, which is considered more modern than their ancestral culture.

In addition to the above-described technology, there are several impacts described by Surahman (2016) which explain the negative impact of the determination of globalization that has hit society and culture in Indonesia, including 1.) There are cultural exchanges where other cultures then recognize many cultures in Indonesia. Such as dances, special foods, and much more. 2.) Indonesian society adheres more to the Western nation's values, resulting in the Indonesian state losing its identity because some western cultures are not following the ideology adopted in the Indonesian state. 3.) Acculturation between western and eastern cultures. Examples such as lifestyle, how to dress, food, how to behave, and some these things are considered detrimental to Indonesia's culture.

\section{Technology changes behavior in matchmaking}

Indonesia is rich in the ideology that is applied in each society according to their culture and customs. In this case, every human being is considered to have an ideology embedded in him through the diversity of ideologies adopted by the Indonesian people, reflecting existing life's identity. Syaifuddin (2006) wrote that Indonesia is seen as an example of a pluralistic society view pluralism because Indonesia has a diversity of societies and cultures. The problem experienced in the past is the lack of interaction with one another, partly due to the archipelago's geographical factor.

That shows the changes experienced by the Indonesian people from ancient times to the present. Some changes occurred, which then eroded the customs and values that were held in Indonesian 
society. Emile Durkheim in Salim (2002) explains that changes that occur in society's structure are a time process that develops to make the population grow rapidly.

In this case, it is someone's matchmaking or marriage. Several parts of Indonesia still have customary provisions to find a mate and get it, as written in Manik (2012), which provides an example of the Toba Batak Community's customs, namely Sinamot. In the Toba Batak community, the Sinamot tradition is used as the basis that must be fulfilled and cannot be eliminated in the traditional Batak Toba marriage. When searching for a mate for children, families will be more selective. Even some families prefer to find and choose a mate for their children to carry out this mandatory tradition, namely Sinamot.

In the Sinamot community culture, it can be seen that many examples of the Jalam community used to think that marriage is an indication of the social status that exists in society. That is as stated by Koentjaraningrat (1994), who wrote that through marriage, the social status of a person in society is also a transition from adolescent to adult status besides marriage through certain customs will also be able to show a higher social status among communities other.

Javanese people do different things in finding a mate or son-in-law in their family. As written by Widayat (2006) explains that the Javanese community is very selective in looking for a partner or son-in-law. The criteria for finding a mate or son-in-law in Javanese society pay attention to bibit, bebet, bobot, and pasatoan salaka rabbi.

Pasatoan salaka rabbi is looking for a mate based on name, birthday, and neptu. At the same time, bibit determines a mate or prospective son-in-law based on the calculation in terms of offspring. Then for bobot, is the determination of a mate and prospective son-in-law in terms of wealth and assets. For bebet determines a prospective son-in-law or a mate based on his social status (Widayat 2006). In addition to these things to determine a mate or partner in Javanese society, there are restrictions on matchmaking as written by Widayat (2006), among others; marriages between brothers and sisters, marriages between in-laws, marriages with former in-laws, marriages with people who are not following neptu, marriages that occur between two brothers and sisters, and the children of two siblings

However, in the current era, with the emergence of technology through online dating applications, people's behavior has begun to change because people are starting to ignore the cultures that bind themselves to get a partner according to their or face. That is also said by Suprapto \& Thay (2018), who says that currently, the motive for looking for a life partner through online users has become a very dominant one because it is considered as easy. Users can search for someone who is near the user.

The motive for the change in behavior that is faced can also have a reason to get personal pleasure. It is meant that humans choose to find a mate through online applications only for their pleasure. Suprapto \& Thay (2018) stated that some users who use online dating applications are just looking for a partner while I am nothing more. However, some users use this application because they have been single for quite a long time.

\section{Features of the Tinder}

In Indonesia's application, technology is no longer a tool that is considered strange or something new. In the emergence of technological advances such as smartphones today, some people change their habits and culture that were very thick in Indonesia in ancient times. In this study, take an analysis of the matchmaking application, namely "Tinder," and see its application in Indonesia. As reported by Pertiwi (2018) in www.tekno.kompas.com, the Tinder application is an application that capitalizes on the internet so that match searches can be easily done. 


\section{'About Me' (personal profile creation)}

In this feature, someone will write their identity. The written identity starts from the name, age, hobbies, occupation, and short profile, showing his strengths. In this feature, a person can also enter a photo of himself or a photo depicting himself, which they think is the best photo so that the person who will be his partner can choose it later. In this feature, it can be seen that where technology can define whom humans use themselves. Lim (2008) explained that technology is used as a means and an end between humans and their world. In this case, it appears that humans try to define their personalities through technology.

Through the interview results, seven informants chose not to keep their identities a secret and gave their best self-portraits, but one informant chose to give an age that was not following her real age. Detailed descriptions of the interview results are as follows.

“Kalau aku sih, identitas, usia, foto semua real tapi pekerjaan nggak aku tunjukin." (Wawancara dengan Fr).

("For me, my identity, age, photos are all real, but I do not show them my job." (Interview with Fr)).

"Identitasku aku samarkan, soalnya kan usia ku masih 17 tahun sedangkan minimal 18 tahun, jadi semua identitas aku nggak tulis real, tapi foto real." (Wawancara dengan Ka).

("I disguise my identity because my age is still 17 years old while at least 18 years old, so I do not write real identities, but real photos." (Interview with Ka)).

"Kalo aku semua asli, kecuali pekerjaan aku nggak masukin ke profil." (Wawancara dengan Me).

("If I am all genuine, except work, I do not enter the profile." (Interview with Me)).

"Identitas, foto, pekerjaan, usia, semua asli dan saya tuliskan." (Wawancara dengan Ra).

("Identity, photo, occupation, age, all original, and I write it down." (Interview with Ra)).

"Semuanya asli kok, pekerjaan nggak aku tulis sih." (Wawancara dengan Ss).

("Everything is original. I do not write work." (Interview with Ss)).

"Semua identitas yang aku tulis dan tampilin asli." (Wawancara dengan La).

("All the identities I write and appear are authentic." (Interview with La)).

"Identitas asli, tapi pekerjaan nggak aku masukan." (Wawancara dengan Ti). ("Original identity, but I did not enter a job." (Interview with Ti)).

The results of these interviews show that more informants chose to show their real identities to their Tinder accounts. However, there are also informants like Ka whose age still does not meet the Tinder application criteria, so that not all Ka's identities are written according to his circumstances. In addition, some informants did not indicate where they worked. According to Waluyo \& Revianti (2019), users also pay attention to identity clarity after carrying out the screening process because users think that this application is still vulnerable, and female users tend to rethink identity clarity than men. However, everyone has different standards. 


\section{Determination of settings (determination of the age and distance of the candidate match)}

This feature provides the vulnerable age that the account owner must choose and how far apart they want a potential partner to be. The farther the distance they choose, the more users will get more potential matches, which the application will provide. In the age range, the expected age is at least 18 years old because, in Indonesia, this age is considered the ideal age to determine a partner. In the book "Menikah Muda di Indonesia" by Grijns et al. (2018), it is also stated that according to research from the Center for Women's Studies at UIN Jakarta in 2000, women's ideal age is around 19.9 years. Moreover, for men, it is 23.4 years.

Based on this research, early marriages have begun to be abandoned. After all, cultural changes occur because most people choose to reduce the tendency to get married at a young age because of the many government programs that do not support early marriage.

\section{Search match}

One of Tinder's features for the first time that created many similar matchmaking features was the "Match" feature. In this feature, users perform a partner search process using the swiping method. Faturochman \& Armando (2014) wrote that in matchmaking on Tinder, this feature is the most important because it most determines whether you can meet the desired partner. This feature shows the perceived pros and cons where the user can manipulate the information on him to accept many candidates.

In this feature, there is an assumption that the Tinder application's match feature is a feature that gives rise to the ancestors' habits, which bring more to life on ancient instincts. As reported by Jemadu (2017), this feature makes choosing a partner based on a shape that is considered the same as the way of the ancestor's thousands of years ago when they were still in the cave. However, in Widayat (2006), this opinion is refuted because there are several customs, such as in Java, where the partner they choose must be a partner who has descent or blood that is considered their ancestor. This contradiction is then used by technology to take advantage of humans to get out of the zone that binds themselves through culture.

The eight female informants like this feature because in this feature, one can choose at will without caring about bibit, bebet, and bobot. Through this feature, eight informants agreed that the most important thing was the good looks on their profiles when they chose a potential partner. The eight informants gave the same vote where all women did not care whether the prospective partner would give the same rating as themself.

\section{Chat and dating}

The next feature is the chat and dating features, wherein this feature someone who has found someone who is considered suitable for themselves in their match feature can chat with that person. Even though this feature, a person can make a closer relationship by having a face-to-face meeting with a previously chosen partner. If users do not get satisfaction with the partner they have chosen, they can do this repeatedly to find the match they think is right. Through this, as said by the theory of determinism technology, according to Nurhadi \& Irwansyah (2018) that humans who have received satisfaction with technology will then cause addiction to human life. The article also explains that technology is an addiction in society. The arguments above are also strengthened through interviews with eight informants who have different ways of responding to or using the dating application.

\section{Change in the culture of matchmaking on Tinder}

In Indonesian culture, marriage is considered as something sacred where it brings together two people who have different personalities. One of Indonesia's unique cultures is to match their offspring with descendants who are considered to be successors or have the same position as their families. One 
Indonesian Journal of Social Sciences Volume 13 No. 01, January-June 2021, page 33-45

example, as written by Widayat (2006), explains that the Javanese community is very selective when it comes to finding a partner or son-in-law. The criteria for finding a mate or son-in-law in Javanese society pay attention to bibit, bebet, bobot, and pasatoan salaka rabbi. That because the ancestors they still adhere to are not lost.

From a religious perspective, one of Indonesia's religions still adheres to a matchmaking system called ta'aruf. In this matchmaking, a person and their partner will meet in a short time. Then they will carry out the marriage as soon as possible. The aim is to maintain the chastity of men and women who are mated. Miftahuljannah (2014) also explains that the process called ta'aruf is getting to know the man he likes through Islamic corridors. The next corridor is direct to a khitbah or proposal, which will lead the two partners to a sacred bond called marriage.

The existence of cultural and religious diversity in Indonesia regarding how to find a mate with each region's uniqueness in Indonesia is threatened with disappearing through the emergence of matchmaking applications. Technology is thought to try to change the sustainability and sanctity of a meeting with a potential partner. From a certain religious perspective, meeting with the opposite sex is considered a very sacred culture. That also leads to the notion that technology changes the sanctity of Indonesia's cultures and religions' diversity. In this case, technology is considered a new religion because it gives rise to a new culture.

Cultural developments and the informants' methods through the Tinder application are ways to make it easier for someone to find their chosen mate more easily. In Indonesian culture, finding a mate has many stages, but the Tinder application's emergence makes it easier for someone to get the life partner or mate they want. Identification of culture and the influence of culture and religion adhered to by people in Indonesia itself greatly influence choosing a partner through this application. Several differences in criteria from the results of interviews conducted by researchers get the following explanation.

\begin{abstract}
"Untuk cari jodoh, aku sama keluargaku tidak memandang etnis, keluargaku juga tahu kalau aku pakai aplikasi online untuk mencari jodoh, dan sampai saat ini aku masih berhubungan dengan jodohku yang aku dapatkan dari aplikasi tersebut dan sudah ingin ke arah yang serius. Lewat aplikasi itu aku sangat dimudahkan sih untuk cari jodoh, soalnya kita bisa deket dulu sama orang lewat chatting setelah kita match. Jadi urutannya itu match,chatting, kemudian aku kasih id line terus kita ketemu dan sampai sekarang. Menurutku sangat efektif karena membantu banget buat aku cari jodoh. Kriteriaku sih yang penting baik, pekerjaan oke, baru seiman." (Wawancara dengan Fr).

("To find a mate, my family and I don't look at ethnicity. My family also knows that I use an online application to find a mate. And until now, I'm still in touch with my soul mate, which I got from the application, and want to take a serious direction. Through this application, it makes it very easy for me to find a mate. Because we can first get close to people via chat after we match. So the order is matched, chat, and then give the id line. We continue to meet until now. I think it is very effective because it really helps me find a mate. My criteria are good, work is okay, new to my faith. "(Interview with Fr)).
\end{abstract}

"Kalo aku sih, keluarga nggak pernah memandang etnis buat dapetin jodoh, motivasiku buat pakai aplikasi tinder ini cuma buat bantu aku biar aku bisa banyak temen sih. Aku juga pengen banyak kenal temen cowok karena aku tipe cewek yang susah ngobrol sama cowok kalo di realitanya, mangkanya aku pake aplikasi ini biar bisa ada temen ngobrol. Belum pernah sampai ketemu sih, yang match banyak yang chat juga banyak, tapi belum ada yang samapai ketemu karena aku orang yang susah buat bersosialisasi sebenarnya." (Wawancara dengan Ka).

("For me, my family has never looked at ethnicity to get a mate. My motivation for using this Tinder application is just to help me so I can have lots of friends. I also want to get to know many male friends because I'm the type of girl who finds it difficult to chat with guys in reality, so I'm using this 
application so that there can be friends chatting. I haven't met you yet, many people match and chat a lot, but no one has yet met because I'm a really difficult person to socialize. "(Interview with Ka)).

"Kalo etnis, keluargaku nggak menuntut etnis apapun sih. Aku pengen pakai tinder karena emang pengen coba-coba dan cari jodoh. Ya.... siapa tahu emg ada yang cocok. Keluargaku nggak tahu sih kalau aku pake aplikasi online karena mereka sebenernya nggak suka dan setuju kalau aku pake aplikasi tinder. Tapi aku ngerasa perlu buat biar aku bisa cepet dapet jodoh. Udah ada beberapa sih yang ketemu tapi memang masih belum banyak yang cocok. Aplikasi tinder ini sangat bantu aku sih buat aku cepet dapet jodoh." (Wawancara dengan $\mathrm{Me})$.

(“As for ethnicity, my family doesn't demand any ethnicity. I want to use Tinder because I really want to try and find my mate. Yes.... who knows if there is a match? My family doesn't know that I use an online application because they really don't like it and agree that I use the Tinder application. But I feel the need to make it so that I can quickly get a mate. There have been several that have met, but there are still not many that match. This Tinder application really helps me so I can get a mate quickly. "(Interview with Me)).

"Buat keluarga saya, etnis nggak terlalu di pentingin sih tapi kalau agama memang keluarga paling utama. Keluarga saya tahu kalau saya pakai aplikasi tinder ini untuk mencari jodoh apalagi dulu saya sudah pernah gagal dalam pernikahan jadi sekarang semua laki-laki yang dekat dengan saya harus melalui persetujuan keluarga dan anak saya terlebih dahulu. Aplikasi ini jelas sangat membantu saya untuk mendapatkan jodoh. Saya sudah sering banget match, chatting dam ketemu dengan pasangan yang saya pilih. Tapi ya mungkin memang belum jodoh saja.” (Wawancara dengan Ra).

("For my family, ethnicity is not really important, but religion is the most important family. My family knows that I use this Tinder application to find a mate. Especially since I have failed in marriage before, so now all men close to me must go through my family and my children's consent first. This application is clearly very helpful for me to find a mate. I have often matched, chatted, and met the partner I chose. But yes, maybe it's not just a mate. "(Interview with Ra)).

"Keluarga aku menuntut sih harus dari etnis yang sama, kalau agama memang keluarga lebih santai sih. Keluarga nggak tau kalau saya pakai aplikasi ini untuk cari pasangan karena mereka tidak memperbolehkan saya untuk pakai-pakai aplikasi lewat online begitu. Menurut aku sih aplikasi ini ngebantu aku banget sih soalnya kan aku jarang banget keluar rumah buat ketemu cowok atau cari cowok gitu. Jadi aplikasi ini banyak bantu aku. Belum pernah ketemu sih, aku lebih nyaman kalau masih deket aja sebatas chatting dulu. Memang belum pengan cari yang serius, cuma pengen banyak kenalan aja." (Wawancara dengan $\mathrm{Pr})$.

("My family demands that it has to be of the same ethnicity if religion is indeed a more relaxed family. My family doesn't know that I am using this application to find a partner because they don't allow me to use the application online. I think that this application really helps me because I rarely go out of the house to meet guys or find guys like that. So this application helps me a lot. I've never met it, I'm more comfortable if I'm still close to just chatting first. I haven't been looking for anything serious yet. I just want lots of acquaintances. "(Interview with Pr)).

"Kalau keluarga ngewajibin aku dari tionghoa juga sih, soalnya dulu pernah pacaran sama jawa tapi nggak dibolehin. Keluarga nggak tahu kalo aku pakai aplikasi tinder, soalnya aku malu sih. Aplikasi ini efektif banget sih buat aku, soalnya kan kalo dulu aku sering tuh di jodoh-jodohin sama keluarga tapi justru nggak ada yang cocok dan buang-buang waktu aku. Kalau ada aplikasi ini kan aku tanpa harus ngeluangin tenaga, uang dll juga karna kan tinggal chatting aja. Kalau ketemu sih udh ada pernah tapi nggak banyak soalnya aku bener-bener pilih yang bisa cocok sama aku setelah kita chatting." (Wawancara dengan Ss).

("My family also obliges me to come from China because I used to date with Java, but it was not allowed. My family doesn't know if I use the Tinder application because I'm embarrassed. This 
Indonesian Journal of Social Sciences Volume 13 No. 01, January-June 2021, page 33-45

application is really effective for me because, in the past, I used to be matchmaking with my family, but none of them matched, and it was a waste of my time. If there is this application, I don't have to spend my energy, money, etc., because I just have to chat. I've met you there, but not many because I really choose those who can match me after chatting. "(Interview with Ss)).

\begin{abstract}
"Sebenernya kalo keluargaku nggak menuntut cuma mereka menyarankan aku buat dari etnis yang sama karena kan biar bisa nikah sama adat. Keluarga nggak tahu pastinya aku pakai aplikasi ini. Aplikasi ini ngebantu aku banget tentunya apalagi di umur-umurku sekarang kan butuh jodoh yang serius dan banyak bertemu dengan calon jodoh semakin bagus. Aplikasi ini ngerubah kebiasaan aku banget sih, soalnya dulu yang manfaatin jarak dan pertemuan, tapi sekarang jadi lebih mudah buat pilih cowok udah sesuai dengan kriteriaku sesuai sama kan kita bisa ketemu kalo kita udah kenal dekat terlebih dahulu." (Wawancara dengan La).

("Actually, if my family doesn't sue, they only suggest that I make it from the same ethnicity because so I can marry in the same way. My family doesn't know for sure I use this application. This application really helps me, of course, especially at my age now. I need a serious mate and meet a lot of potential matchmakers, the better. This application really changes my habits, because in the past it used distance and meetings, but now it's easier to choose a guy who fits my criteria according to the same, right? We can meet if we get to know him first. "(Interview with La)).
\end{abstract}

\begin{abstract}
"Keluarga nggak pernah menuntut yang kayak gimana tapi menyarankan dari etnis dan agama yang sama sih. Aku nemun jodohku lewat aplikasi tinder ini, walaupun belum menikah namun kita sudah serius ke arah menikah sih. Dulu lewat aplikasi ini aku match-chatt- trus ketemunya masih lumayan lama setelah kita deket di chat. Aku baru pertama kalo pakai aplikasi ini tapi langsung dapet jodoh yg pacaran sampai sekarang. Dulu aku pacaran langsung ketemu gitu baru jatuh cinta, tapi yang ini aku justru jatuh cinta baru ketemu." (Wawancara dengan Ti).

("The family never demands what is like what, but they recommend people from the same ethnicity and religion. I found my soul mate through this Tinder application. Even though I wasn't married yet, we were serious about getting married anyway. In the past, I used this application to match-chat, then I found it still quite a long time after we were close in chat. I just used this application for the first time but immediately got a dating mate until now. I used to go out and meet right away when I fell in love, but I fell in love and just met this time. "(Interview with Ti)).
\end{abstract}

When interviewed, eight informants who chose to use the Tinder application had already been matched by their families according to their family's choice. However, eight informants chose not to follow their family's choice. Through interviews, it shows that ethnicity and culture had not become too important at this time.

According to Kusumaningtyas \& Hakim (2019), no barrier separates people from one culture to another to become fused. Likewise, with the selection of a mate. The Tinder application then emerged by providing a change in attitude and culture about getting a mate through cyberspace. The cultural change in question lies in the example above, which describes the many different cultures that a woman joins in looking for her soul mate without knowing ethnicity, bibit, bebet, and bobot, they are looking for at first. Informants tend to choose a partner that fits their criteria, for example, the informant who has the criteria for a partner who has good character, a good job, and is also of the same religion as him. Some informants also stated that in looking for a mate, there were also those related to the family's criteria. Some of the informants' families stated that they had to consider ethnicity or religion. This family desire is related to ethnic and religious similarities. According to Christian (2017), if the married couple comes from a different subgroup from them, then the two families' marriage customs will become an essential main discussion. However, through the tinder feature, namely "match", almost all female interviewees take advantage of the "match" feature to find 
a mate according to their wants, not what their family wants. Although several informants have met their "match" partners, some informants are not matching, so they chat as friends.

\section{Conclusion}

Technology in Indonesia's journey gave rise to culture and was considered an addiction to a new society. That is because of the many shortcuts raised, which then creates an addiction for people to continue using this technology. In this case, the technology taken or adopted is a matchmaking application, namely "Tinder." Some of the features raised by Tinder always bring up a new controversy and addiction to the community. Due to the emergence of the Tinder application at this time in Indonesia, similar applications have started to appear with the same goal. This cultural change then creates Indonesia problems because of the many cultural orders or rules that humans violate by humans. This is enforced as explained by determinism technology. Technology will enslave humans, and technology will cause addiction to the surrounding environment.

The choice of the tinder application was initially favored because humans assumed that humans could avoid mythical things with many explanations about why couples had to meet certain customs or methods. However, the transfer of methods to the Tinder application can actually handcuff humans to form a new culture, making it possible if the individual cannot escape from it. That's because a new culture is not only addictive but will actually make humans return to early human life. The assessment of this Tinder application and the "match" feature was also approved by 8 female informants interviewed by the researcher. They think this application makes it easier and makes them addicted to using the application to find a mate.

\section{References}

Astuti AP \& Rps AN (2014) Teknologi komunikasi dan perilaku remaja. Jurnal Analisa Sosiologi 3 (1):91-111.

Christian SA (2017) Identitas budaya orang Tionghoa Indonesia. Jurnal Cakrawala Mandarin 1 (1):11-22.

Faturochman A \& Armando N (2014) Penggunaan Tinder dan pengembangan hubungan dengan match dalam Tinder (Studi terhadap mahasiswa/i Universitas Indonesia pengguna Tinder). FISIP:1-20. [Diakses Juni 2019]. http://lib.ui.ac.id/naskahringkas/2016-05/S57216-Ayip\%20 Fahmi\%20Faturochman.

Grijns M, Horii H, Irianto S, \& Saptandari P (2018) Menikah Muda di Indonesia; Suara, Hukum, dan Praktik. Jakarta: Yayasan Pustaka Obor Indonesia.

Irena A (2017) Tahu gak sih, 7 tradisi pernikahan di Indonesia ini sangat unik. [Diakses 14 Juni 2019]. https://www.idntimes.com/life/relationship/angelin-irena-natalia/tujuh-tradisi-unik-adat-pe rnikahan-di-indonesia-c1c2.

Jek (2018) Para jomblo, simak 5 aplikasi kencan online paling hits di 2018. [Diakses 15 Juni 2019]. https://www.liputan6.com/tekno/read/3568815/para-jomblo-simak-5-aplikasi-kencan-online-pali ng-hits-di-2018.

Jemadu L (2017) Studi: Manusia modern menjadi manusia purba berkat Tinder. [Diakses 15 Juni 2019]. https://www.suara.com/tekno/2017/10/19/175257/studi-manusia-modern-menjadi-manusia -purba-berkat-tinder

Koentjaraningrat (1994) Kebudayaan Mentalitas dan Pembangunan. Jakarta: Gramedia

Koentjaraningrat (2002) Pengantar Ilmu Antropologi. Jakarta: Rineka Cipta.

Kusumaningtyas AP \& Hakim AI (2019) Jodoh di ujung jempol: Tinder sebagai ruang jejaring baru. SIMULACRA 2 (2):101-114.

Lim F (2008) Filsafat Teknologi: Don Ihde Tentang Dunia, Manusia, dan Alat. Yogyakarta: Kanisius. 
Manik HS (2012) Makna dan fungsi Tradisi Sinamot dalam adat perkawinan sukubangsa Batak Toba di Perantauan Surabaya. BioKultur 1 (1):19-32.

Martono N (2011) Sosiologi Perubahan Sosial: Perspektif Klasik, Modern, Postmodern, dan Poskolonial. Jakarta. PT. Raja Grafindo Persada.

Maryono Y \& Istiana B (2007) Teknologi Informasi dan Komunikasi. Yogyakarta: Penerbit Yudhistira.

McLuhan M (1964) Understanding Media: The Extensions of Man. New York: McGraw-Hill

McLuhan M (1994) Understanding Media: The Extensions of Man. London: The MIT Press.

McLuhan M (2003) Understanding Media: The Extensions of Man. London \& New York: Gingko Press.

Miftahuljannah H (2014) A-Z Taaruf, Khitbah, Nikah, \& Talak Bagi Muslimah (Indonesian Edition). Indonesia: Gramedia Widya Sarana Indonesia.

Mirza A \& Dewi A (2019) Revolusi Industri 4.0. Jawa Barat : CV Jejak Anggota IKAPI.

Nurhadi W \& Irwansyah (2018) Crownfunding sebagai konstruksi sosial teknologi dan media baru. Jurnal Komunikasi dan Kajian Media 2 (2):1-12.

Pertiwi W (2018) Facebook Sedang coba Fitur Kencan Ala Tinder. [Diakses 15 Juni 2019]. https://tekno.kompas.com/read/2018/09/24/11544067/facebook-sedang-coba-fitur-kencan-ala-tin der?page $=$ all.

Salim A (2002) Perubahan Sosial: Sketsa Teori dan Refleksi Metodologi Kasus Indonesia, Yogyakarta: Tiara Wacana Yogya.

Setianto B \& Anandhita G (2018) Unika Dalam Wacana Publik: Transformasi Inspiratif. Semarang: Unika Soegijapranata.

Suprapto H \& Thay V (2018) Relationship for Cyberspace. Jakarta: PT Elex Media Komputindo.

Surahman S (2016) Determinisme teknologi komunikasi dan globalisasi media terhadap seni budaya Indonesia. Jurnal Rekam 12 (1):31-42. doi.org/10.24821/rekam.v12i1.1385.

Syaifuddin AF (2006) Membumikan multikulturalisme di Indonesia. Jurnal Antropologi Sosial Budaya ETNOVISI II (1):3-10.

Waluyo LS \& Revianti I (2019) Pertukaran sosial dalam online dating (studi pada pengguna Tinder di Indonesia). Jurnal Informatik 15 (1):21-38.

Want more matches? Tinder CEO suggests the perfect profile photo (2016) [Diakses Juni 2019]. https://gadgets.ndtv.com/apps/news/want-more-matches-tinder-ceo-suggests-the-perfect-profilephoto- 828467

Widayat A (2006) Metruk; menyuarakan karakter Orang Jawa. Kejawen: Jurnal Kebudayaan Jawa 1 (2):79-90. 